\title{
The Correlation of Leadership Practices of First and Second Generation Family Business Owners to Business Performance
}

\section{JP van der Westhuizen PhD.}

Vaal University of Technology johanvdw@vut.ac.za

Andrea Garnett PhD.

North-West University, Vaal Triangle Campus andreagarnett@yahoo.com

\section{Doi:10.5901/mjss.2014.v5n21p27}

\begin{abstract}
Family firms are a major contributor to many economies. However, very few of these businesses will continue to exist after the first generation due to succession failure. Family business leaders need to learn how to manage the factors that affect the succession process. Researchers in family business literature acknowledge that leadership is vital to the success and survival of the firm, although the high failure rate of family businesses in the second and later generations indicates that the succeeding generations might not have developed sufficient leadership practices to sustain business performance. The aim of this research study was to investigate whether there is a correlation between leadership practices and business performance amongst first and second generation owners of family firms. A self administered, quantitative survey questionnaire, measuring leadership practices and business performance was distributed via means of a non-probability, snowball sampling method to 197 first and second generation family business owners in the Sedibeng region of South Africa. The findings indicate that positive significant correlations exist between the occurrence of leadership practices and business performance for first generation leaders of the selected family businesses, but limited correlations exist between the variables for the second generation leaders. These results illuminate the potential differences in the ways that first and second generation leaders lead family businesses. To this end, propositions are offered to assist founders in training future leaders.
\end{abstract}

Keywords: Leadership practices, family business, first generation, successors, business performance

\section{Introduction}

The importance of family businesses were until the early 90 s, somewhat overlooked in most developing and emerging economies around the world. Their true value and contributions were only appreciated when the challenges of unemployment and poverty started to cause social and political problems and uncertainty.

Today, family businesses are the dominant form of business enterprise in both developed and developing countries. (Gersick, et al., 1997; Lee, 2006) and make an important contribution to economic growth and wealth creation in the world (Poza, 2010; Basu, 2004, Morck \& Yeung, 2004; Astrachan \& Shanker, 2003; Ibrahim, Soufani \& Lam, 2001). For example, in France and Germany the majority of the 250 largest listed companies are family dominated (IFERA, 2003). In Spain, statistics indicate that 50 percent of the top 3000 firms are family owned. In the USA and Canada it is estimated that family businesses make up 90 percent of all businesses (Astrachan \& Kolenko, 1994), and 35 percent of the 500 biggest companies are family owned (Lee, 2006; Longenecker et al., 2006). South Africa is no exception in this regard, as it is estimated that 80 percent of businesses in South Africa could be classified as family businesses and these businesses comprise 60 percent of the companies listed on the Johannesburg Stock Exchange (Ackerman, 2001). Maas, Van der Merwe and Venter (2005) are of the opinion that, because of the important role family businesses perform in the South African economy, their survival is of utmost importance.

Family businesses, unfortunately, lack longevity; very few family businesses survive to the second generation and considerably less continue to the third (Bareither \& Reischl, 2003; Lea, 1991). Approximately 85 percent of all new businesses fail. Among those that survive, only 30 percent are successfully transferred to the second generation of the founding family owners (Poza, 2014). A large number of family businesses fail because of succession failure (Ibrahim \& Ellis, 2004; Kets de Vries, 1996), mainly as a result of the inability of family businesses to manage this complex process 
of transferring ownership and management to the next generation (Bareither \& Reischl, 2003; Lansberg, 1999), and lack of management to sustain a family business (Aronoff et al., 2002).

Poza (2014) views succession as the most critical and important issue facing family firms. Succession is so important to family firms that Ward (1987) chose to define family firms in terms of their ability to achieve succession and research reports that 70 percent of family businesses fail to pass the first test of succession (Lansberg, 1988; Handler, 1994). This represents an enormous loss of productivity to the economy. Many authors believe that this inability could be one of the most important reasons for the high failure rate among first- and second-generation family businesses (Corbetto \& Salvato, 2004). The need to identify and understand the factors that influence generational succession in family businesses becomes apparent.

Researchers in family business literature acknowledge that leadership is vital to the success and survival of the family firm (Fiedler, 1996), for the following reasons: firstly, family firms may have different goals than publicly owned businesses (Chrisman et al., 2003). Secondly, when compared to non-family firms, family businesses have a greater potential for long-term conflict among involved members (Morris et al., 1997). Finally, the process of leadership succession is far more important for family firms than non-family firms because of a stronger link to firm survival (Rubenson \& Gupta, 1996).

\section{Literature Review}

\subsection{Family business and succession}

There is no universally accepted definition of a family business in the literature or among teaching and consulting communities, the public, or even family business owners (Poza, 2014; Astrachan et al., 2002; Flören, 2002; Littunen \& Hyrsky, 2000). Since its inception, the field of family business studies has struggled with a need to define its boundaries and source of distinctiveness. Although family businesses resist easy definition (Lee, 2006), almost all researchers agree on the necessity of having a definition (Flören, 2002). Consequently, clarifying a definition for a family business is the first and most obvious challenge facing the family business researcher (Handler, 1994). Poza (2010) proposes the following working definition:

(1) Ownership control of 15 percent or higher by two or more members of the single family or a partnership of families; (2) Strategic influence by the family members on the management of the business; (3) Concern for family relationships; (4) The possibility of continuity across generations.

The more successful the transfer of ownership, the better the chances of success and long-term profitability. It is a delicate process, and a well-considered and planned succession will increase the chances of finding a competent successor and will ensure a smooth transition between generations (Poza, 2014; Neubauer \& Lank, 1998; Murray, 2003).

A major challenge in some family businesses is that the owners are reluctant to do succession planning (Ibrahim et al., 2010). Reasons may be that the owners see the loss of power and status as the result of retirement. Many founders have worked so hard their entire lives that they value the control of the business above anything else.

Researchers have suggested that the individual most responsible for the continuity of the family business is the founder or incumbent leader. The attributes of owners that have brought them success in the business may prove to be hurdles in the process of transferring the ownership to the next generation to ensure the survival of the business. The aim of the founder to transfer the business to future generations is a key defining element of continuing a family business (Poza, 2014; Astrachan \& Shanker, 2003). Issues that need careful consideration involve integrating the family, business and ownership roles, and a successor lacking the necessary leadership skills may affect the continuity of the business (Poza, 2010; Ibrahim et al., 2004).

Until the founder makes the decision to involve the family and pass the business on to the next generation, the founder remains essentially an entrepreneur or small business owner (Gersick et al., 1997). Moreover, the leadership style of the successor may be different because of the difference in role perception. The successor must understand their own level of risk-taking propensity to enhance their own development as a leader (Cater \& Justis, 2009).

Barach and Ganitsky (1995) believe that the succession process is a time for the outgoing leader to assist the younger leader with educational and operational opportunities, and it is a time for potential successors to fine-tune their own expertise, along with understanding the family values and special competencies.

\subsection{Challenges promulgating failure in the succeeding generation}

It has been estimated that only 30 percent of family businesses successfully transfer to the second generation, 10 to 15 
percent to the third generation and only three to five percent successfully survive to the fourth generation, according to Aronoff (1998), and later supported by Poza (2010) and Tio and Kleiner (2005). In South Africa, only one in four family businesses survive into the second generation, and one in ten makes it to the third generation (Hugo, 1996).

The founder's inability to move on was found to be a major factor inhibiting succession (Sharma et al., 2003). Girard (1996) states that jealousy is inevitable due to human desire. Therefore, in the context of the family business, the founder may support and encourage their heir to take charge of the business, but at the same time, refuse to let go of control. Conflict and rivalry within the family may then result in a failure in succession. The founder's general type of behaviour during the succession process will lead some businesses to fail regardless of the successor's abilities (Grote, 2003). As a result, family business leaders lacking the necessary leadership skills, which include relinquishing control, may affect the ultimate success of the business (Ibrahim et al., 2004).

\subsection{Family business and leadership}

Scholars in family business literature acknowledge that leadership is vital to the survival and success of the business. Leadership is one of social science's most examined phenomena (Day \& Antonakis, 2012). This is not surprising, seeing that it is a worldwide activity evident in humankind and in animal species (Bass \& Bass, 2008).

Most leadership scholars would concur that leadership can be defined in terms of (a) an influencing process and its outcomes that occur between a leader and followers and (b) how this influencing process is explained by the leader's characteristics and behaviours, follower perceptions and attributes of the leader, and the context in which the influencing process occurs.

Other authors posit that leadership can be measured and taught (Kouzes \& Posner, 2012; Avolio \& Bass, 1998).

\subsection{Kouzes and Posner's Theory of Exemplary Leadership}

This theory of Kouzes and Posner (2012) showed that the study of leadership and practices leaders use in organisations originates with the relationship between aspiring leaders and followers to accomplish extraordinary goals. Without understanding these relational connections between leaders and followers, strategic tactics, skills and practices are meaningless. As a result, their research began 25 years ago and focused on finding out what essential qualities the followers most look for and admire in a person they would be willing to follow.

Their findings reveal there are four qualities that dominate. These include emotional satisfaction, shared visions of the future, a focus on trust and collaborative relationships (Kouzes \& Posner, 2012). They realised over time that these fundamentals remained constant even if the context of leadership situations changed.

While observing leaders who performed successfully and studying those specific situations, Kouzes and Posner (2012) developed a theory of exemplary leadership, which is a model developed from their research findings. They believe that average leaders can be developed into extraordinary leaders through practices that can be learned. Their work led to the development of the leadership practices inventory (LPI), which is the basis of the measuring instrument used in the study that this article is based on.

The prominent attribute about the five practices of exemplary leadership is that they are attainable by leaders in smaller capacities, unlike the other neo-charismatic leadership theories, which focus on leaders of large companies.

Overall, the relationship between leadership attributes and economic performance indicators of the business are supported by researchers in the literature (Collins, 2005; Duffy Atkin, 2002). However, studies focusing on relationships between leadership and business performance are rare. A similar study was done by Weaver (2008) in the USA, but no scholarly work related to the abovementioned factors could be identified in South Africa. Weaver (2008) suggests the field needs studies testing the association between the two dimensions to expand the validity of these results.

\section{Purpose of the Study}

This research study seeks to explore the leadership practices displayed or used and the relationship to business performance for first generation and second generation family business leaders located in the Sedibeng region of South Africa.

It is envisaged that the survival rate for family businesses could improve if the identification of successful leadership practices is distinguished. First generation leaders may then encourage second-generation leaders to take steps to develop such practices or otherwise consider the presence or absence of such practices when deciding on a successor. 


\section{Research Methodology}

\subsection{Participants}

The population for this study consisted of small and medium sized family businesses in the Sedibeng District and the Metsimaholo municipality in Southern Gauteng in South Africa. The definition of a family business, as outlined by lbrahim and Ellis (2004), has been adopted as the definition for the purpose of this study. To be classified as a family business, the following requirements must be met: (1) At least 51 percent of the business must be owned by the family; (2) At least two family members must be involved in the management of the business; (3) The transfer of leadership to the next generation of family members must be anticipated.

Weaver (2008) conducted a similar study in the United States and used a convenience sample of 183 family business leaders. This substantiates the 197 small and medium sized family business owners that made up the sample for this study.

Because the study was exploratory the only inclusion criteria was that the respondents were either first or second generation family business owners.

\subsection{Instrument}

The leadership practices inventory (LPI) used in this study formed the basis for determining the differences in the type of leadership practices present in first and second generation family business leaders. The leadership practices inventory was appropriate for the current study because of its documented validity and application in a wide range of situations (Weaver, 2008; Enger, 2004; Kouzes \& Posner, 2012).

This LPI assessment gives feedback to leaders on their performance with respect to five practices of exemplary leadership: (a) model the way (refers to setting an example and standing up for beliefs), (b) inspire a shared vision (adopting a positive outcome for the organisation and sharing that vision with others), (c) challenge the process (embracing change and risk taking), (d) enable others to act (by fostering collaborative efforts and sharing power), and (e) encourage the heart (exemplary leaders celebrate victories and recognise follower contributions). The leadership practices inventory (LPI) includes a ten-point Likert scale with 1 denoting almost always and 10 denoting almost never. The five practices are evaluated by six dimensions each on the leadership practices inventory.

In addition, the respondents completed a business performance and demographic questionnaire with specific business performance indicators, which will be discussed in the next section.

\subsection{Business performance indicators}

According to Chaharbaghi and Willis (1999), business performance is broadly viewed from two perspectives namely, an objective and subjective measure. Where objective measures refer to financial aspects, subjective measures test the non- economic performance of the business.

Matsuno and Mentzer (2000) also support the concept that business performance should be viewed not only as economic performance (concrete figures representing business performance) but also as non-economic performance (customer satisfaction, social acceptance, corporate image and employee satisfaction).

The objective business performance measures include various financial aspects of the business, such as figures gleaned from the businesses financial statements. These figures can include sales turnover, profit margins, investment returns, staff turnover rates and other ratios developed from financial statement information (Plakoyiannaki et al., 2008; Lee, 2004). An additional objective measure of economic performance is the change in the number of employees over time. In a multidimensional approach, Haber and Reichel (2005) asked respondents in a study of small tourism ventures to indicate profitability, revenues, and number of employees for each of three years. They found that an increase in revenues had a positive correlation with an increase in the number of employees.

Researchers have historically used subjective measures of business performance for research on small privately held firms because of the unavailability of publicly accessible, objective financial information (Miller \& Besser, 2005). In addition, many private firm owners were reluctant to provide confidential financial statements to researchers, preferring to respond to the questions themselves (Miller \& Besser, 2005; Wolff \& Pett, 2006). Miller and Besser (2005) asked respondents to indicate the prior year's sales in an open-ended question, and Wolff and Pett employed a five-point Liker type scale for questions comparing the firm's performance to competitors in the industry. In a similar manner, Rasheed (2005) asked respondents whether the sales and profits for the business increased, remained the same, or decreased 
each year over the past three years.

Obtaining financial information in this manner helps to ascertain the change in business performance over time as well as the position of the company within the industry (Miller \& Besser, 2005; Rasheed, 2005; Wolff \& Pett, 2006). The perception of profitability relative to similarly situated businesses is a useful measure in a multi-dimensional approach (Wolff \& Pett, 2006). The final measure of business performance relates to the owners' perception of satisfaction in the leadership position.

Therefore, the business performance indicators for this study included the following questions: (a) annual sales for the business for 2009, 2010 and 2011; (b) the average number of employees for 2009, 2010 and 2011; (c) the leader's perception of the profitability of the business as compared to similar sized businesses (determined on a 5-point Likert scale), and; (d) the leader's level of satisfaction with the leadership role in the business.

\subsection{Data collection methods}

The researchers conducted the fieldwork for the study personally. Because, of the absence of officially compiled databases for family businesses, the only available option was to rely on snowball sampling as the sampling method.

A starting point was to obtain a preliminary list of all businesses from the local business chambers, and from there the researchers identified a number of family businesses. The approach used was to make telephonic appointments with those respondents who met the requirements for the study. During the meeting, the researchers briefly described the research topic, reason for the study, possible outcomes expected from the study and the anticipated advantages for the family business leaders. The respondents were informed of the principle of voluntary participation, privacy, and the fact that they could withdraw from the study at any time.

A total number of 250 self- administered questionnaires were delivered or e-mailed to the accessible population of small and medium-sized family businesses and later collected. Of the 250 questionnaires distributed, 197 were returned, which is a response rate of 78.8 percent.

\section{Findings and Discussion}

\subsection{Demographic profile of respondents}

The profile of respondents comprised 150 first generation and 47 second generation leaders, representing 76.1 percent and 23.9 percent of the family businesses respectively. For the first generation leaders, 32 percent were over the age of 60 , thereby demonstrating their desire to remain involved in the business close to their retirement age. Perhaps another possible explanation is that many family businesses have not done succession planning or there may be no willing family members to take over the businesses, as was the case in research conducted by Van Duijn et al. (2007) and Rwigema and Venter (2004).

In addition, 80 percent of the first generation family business leaders had more than 20 years of experience in a leadership position. For the second generation, the majority of the respondents in this study were under the age of 40 and had 5 years and less (100\%) experience as a leader.

In addition, all the respondents employed fewer than 200 employees. The annual sales/ turnover for the three years ranged from R700 000 to R165 000000 for the first generation family businesses, and between R550 000 and R103 000000 for the second generation family businesses. Various family business leaders were reluctant to report actual sales figures and offered the percentage of change in sales from 2009 to 2010 and 2011. This was acceptable because the scoring of this business performance indicator considered the change in sales for the above-mentioned years.

\subsection{Reliability and validity}

A measurement model of the conceptual model with six latent variables was estimated. All constructs were modelled using reflective indicators. Construct reliability was assessed by three methods, Cronbach's alpha test (Cronbach's a), composite reliability test (CR) and average value extracted (AVE) test. The results are presented separately for the first generation and second generation leaders in Table 1 and 2 respectively. 
Table 1: First generation leaders

\begin{tabular}{|l|c|c|c|}
\hline Construct & Cronbach Value & CR Value & AVE Value \\
\hline Model the way & 0.778 & 0.702 & 0.530 \\
\hline Inspire a shared vision & 0.819 & 0.754 & 0.512 \\
\hline Challenge the process & $0.752:$ & 0.741 & 0.582 \\
\hline Encourage others to act & 0.869 & 0.715 & 0.530 \\
\hline Encourage the heart & 0.796 & 0.709 & 0.599 \\
\hline Business performance & 0.773 & 0.723 & 0.601 \\
\hline
\end{tabular}

Table 2: Second generation leaders

\begin{tabular}{|l|c|c|c|}
\hline Construct & Cronbach Value & CR Value & AVE Value \\
\hline Model the way & 0.742 & 0.749 & 0.531 \\
\hline Inspire a shared vision & 0.767 & 0.749 & 0.563 \\
\hline Challenge the process & 0.775 & 0.771 & 0.569 \\
\hline Encourage others to act & 0.766 & 0.773 & 0.589 \\
\hline Encourage the heart & 0.734 & 0.729 & 0.539 \\
\hline Business performance & 0.741 & 0.734 & 0.533 \\
\hline
\end{tabular}

Cronbach alphas of above 0.73 were reported for all the constructs in the scale, for both first and second generation leaders, which is above the acceptable level as suggested by Nunnally (1978) and indicates that the scale is consistent and reliable. All of the items loaded on the six predetermined factors as expected, indicating the uni-dimensionality of the scale. The internal reliability of each construct was also evaluated using the composite reliability (CR) index test. A composite reliability index that is greater than 0.7 depicts an adequate internal consistency of the construct (Hair et al., 2010). AVE values greater than 0.50 (Hair et al., 2010; Neuman, 2006) reveal that the indicators represent the construct well. The CR and AVE values are all above the recommended measures, therefore, signifying that the measuring instrument used to measure the constructs is internally reliable and consistent (Hair et al., 2010).

\subsection{Structural equation modelling (SEM)}

The structural model was tested using the loadings and significance of the path coefficients (indicating the strength of relationships between dependent and independent variables), and the $\mathrm{R}^{2}$ value (the amount of variance explained by independent variables).

The statistical significance of each path was estimated using a Smart PLS bootstrapping method utilising 100 resamples to obtain t-values (Hair et al., 2010). Support for the study hypotheses (refer to Table 3 and 4), which are labelled on their corresponding paths in Figure 1 and 2 could be ascertained by examining the directionality (positive or negative) of the path coefficients and the significance of the t-values. The standardised path coefficients are expected to be at least 0.2 and preferably greater than 0.3 (Hair et al., 2010).

Figure 1: Structural model results - first generation

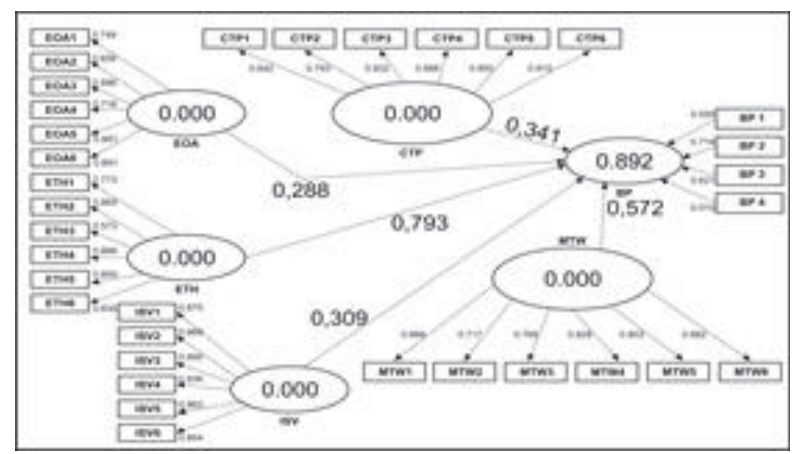


For the first generation, the $\mathrm{R}^{2}$ value for the dependent variable - business performance (BP) is 0.892 . This indicates that the five leadership practices explain about 89.2 percent of the variance in business performance (BP), hence suggesting that these variables almost fully explain the variations in business performance indicators for the first generation family businesses.

Figure 2: Structural model results - Second generation

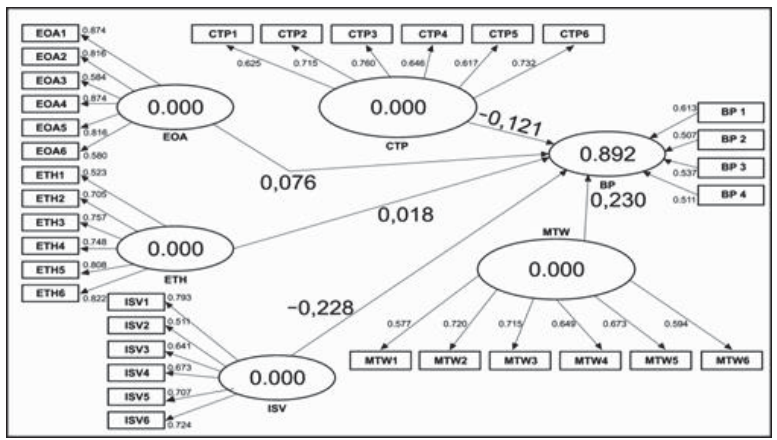

For the second generation, the $\mathrm{R}^{2}$ value for business performance (BP) is 0.129 . This finding suggests that the leadership practices explained only 12.9 percent of the variance in business performance (BP), indicating that the leadership practices employed by second generation leaders did not have a significant impact on business performance.

\subsection{Hypotheses testing for first generation leaders}

The corresponding path coefficients of the research hypotheses indicate observable existence of positive relationships between the five individual leadership practices and business performance for first generation family business leaders. A summary of these significant relationships is represented in Table 3.

Table 3: SEM analysis - first generation

\begin{tabular}{|c|c|c|c|}
\hline Proposed Hypothesis Relationship & Path Coefficients & T-Statistics & Rejected / Supported \\
\hline $\begin{array}{l}\mathrm{H}_{a} \text { la. There is a significant positive association between the } \\
\text { individual leadership practice (1) model the way and business } \\
\text { performance for the first generation family business leaders. }\end{array}$ & 0.572 & $3.423^{*}$ & Supported \\
\hline $\begin{array}{l}\mathrm{H}_{a} 2 \mathrm{a} \text {. There is a significant positive association between the } \\
\text { individual leadership practice (2) inspire a shared vision and business } \\
\text { performance for the first generation family business leaders. }\end{array}$ & 0.309 & $3.018^{*}$ & Supported \\
\hline $\begin{array}{l}\mathrm{H}_{a} 3 \mathrm{a} \text {. There is a significant positive association between the } \\
\text { individual leadership practice (3) challenge the process and business } \\
\text { performance for the first generation family business leaders. }\end{array}$ & 0.341 & $2.929 *$ & Supported \\
\hline $\begin{array}{l}\mathrm{H}_{a} 4 \mathrm{a} \text {. There is a significant positive association between the } \\
\text { individual leadership practice (4) enable others to act and business } \\
\text { performance for the first generation family business leaders. }\end{array}$ & 0.288 & $2.243^{\star}$ & Supported \\
\hline $\begin{array}{l}\mathrm{H}_{a} 5 \mathrm{a} \text {. There is a significant positive association between the } \\
\text { individual leadership practice (5) encourage the heart and business } \\
\text { performance for the first generation family business leaders. }\end{array}$ & 0.793 & $3.434^{*}$ & Supported \\
\hline
\end{tabular}

*Significance level of +1.96

Hypotheses 1 to 5 show positive and significant relationships between each of the leadership practices and business performance. The results indicate a positive $(\beta=0.572)$ and significant $(t=3.423)$ relationship between the leadership practice model the way and business performance. For hypothesis 2 , the results show a positive $(\beta=0.309)$ and significant ( $t=3.018)$ correlation between the leadership practice inspire a shared vision and business performance, Similarly Hypotheses 3 (challenge the process); 4 (enable others to act) and 5 (encourage the heart) showed positive and significant relationships with business performance. As a result, $\mathrm{H}_{a} 1 \mathrm{a}, \mathrm{H}_{2} 2 \mathrm{a}, \mathrm{H}_{a} 3 \mathrm{a}, \mathrm{H}_{a} 4 \mathrm{a}$ and $\mathrm{H}_{2} 5 \mathrm{a}$ are supported. 
For leaders to effectively model the way, they should first be clear about their own guiding principles. Leaders' deeds are far more important than their words. Exemplary leaders set an example by aligning their actions with shared values. Hence, a leader who sets a good example will positively affect the performance of the business.

Leaders describe their personal best leadership experience as times when they imagined an exciting, highly attractive future for their businesses. They had visions of what could be. Leaders envision the future by imagining exciting possibilities such as growth in market share and an overall increase in business performance, which has ostensibly influenced the results of the family firm. First generation business founders are likely to have had this vision in mind when beginning the firm, due to their own entrepreneurial orientations and have been able to transfer this vision to their employees, who subsequently influence business performance positively.

No leader can claim to have achieved a personal best by maintaining the status quo. Leaders who challenge the process venture out, they do not sit idly by and wait for things to happen. These leaders have to look constantly outside themselves and the business to search for opportunities and by looking outward for ways to improve. This continual seeking of improvement is bound to have an impact on business performance.

An organisational vision will not be realised through the actions of one individual only; it requires a team effort. It necessitates trust, commitment and strong relationships. This sense of teamwork extends beyond a few direct instructions, and these leaders typically engage and enable all employees to act to ensure the performance of the business.

It has been shown by $\mathrm{H}_{2} 5 \mathrm{a}$ that a greater level of encouraging the hearts of employees is related to higher levels of business performance. Leaders recognise contributions by showing appreciation for individual excellence, and these acts of caring draw people forward. These leaders are often on the lookout for ways to create an environment in which people feel cared about and appreciated. Acknowledging aspects during a project that was successful and giving positive feedback to people who deserve credit is very important. It builds morale and contributes to a more cooperative work environment. The first generation leaders, possibly due to their investment and involvement in the family firms, were able to model all these leadership practices successfully.

\subsection{Hypotheses testing for second generation leaders}

The five hypotheses tested for the first generation leaders were similarly assessed from the data gathered from the second generation leaders via means of SEM. The results are outlined in Table 4.

Table 4: SEM analysis - second generation

\begin{tabular}{|c|c|c|c|}
\hline Proposed Hypothesis Relationship & Path Coefficients & T-Statistics & Rejected/ Supported \\
\hline $\begin{array}{l}\mathrm{H}_{a} \mathrm{lb} \text {. There is a significant positive association between the individual } \\
\text { leadership practice (1) model the way and business performance for } \\
\text { the second generation family business leaders. }\end{array}$ & 0.195 & 0.736 & Rejected \\
\hline $\begin{array}{l}\mathrm{H}_{2} 2 \mathrm{~b} \text {. There is a significant positive association between the individual } \\
\text { leadership practice (2) inspire a shared vision and business } \\
\text { performance for the second generation family business leaders. }\end{array}$ & -0.228 & 0.082 & Rejected \\
\hline $\begin{array}{l}\mathrm{H}_{3} 3 \mathrm{~b} \text {. There is a significant positive association between the individual } \\
\text { leadership practice (3) challenge the process and business } \\
\text { performance for the second generation family business leaders. }\end{array}$ & 0.118 & $1.998^{*}$ & Supported \\
\hline $\begin{array}{l}\mathrm{H}_{a} 4 \mathrm{~b} \text {. There is a significant positive association between the individual } \\
\text { leadership practice (4) enable others to act and business performance } \\
\text { for the second generation family business leaders. }\end{array}$ & 0.076 & 1.370 & Rejected \\
\hline $\begin{array}{l}\mathrm{H}_{2} 5 \mathrm{~b} \text {. There is a significant positive association between the individual } \\
\text { leadership practice (5) encourage the heart and business performance } \\
\text { for the second generation family business leaders. }\end{array}$ & -0.121 & $2.019^{*}$ & Supported \\
\hline
\end{tabular}

*Significance level of +1.96

Hypothesis $\mathrm{H}_{a} \mathrm{Ib}$ posited a positive relationship between the leadership practice model the way and business performance. The results show a positive $(\beta=0.195)$ but insignificant $(t=0.736)$ association between the leadership practice model the way and business performance and the hypothesis is thus rejected. Hypothesis $\mathrm{H}_{2} 2 \mathrm{~b}$ is similarly rejected as the results indicate a negative $(\beta=-0.228)$ and insignificant $(t=0.082)$ relationship between the leadership practice inspire a shared vision and business performance. 
Hypothesis $\mathrm{H}_{a} 3 \mathrm{~b}$ posited a positive association between the leadership practice encourage the heart and business performance. Table 4 indicates that there is a positive $(\beta=0.118)$ and significant $(t=1.998)$ association between the leadership practice and business performance. Therefore, $\mathrm{H}_{a} 3 \mathrm{~b}$ is supported. $\mathrm{H}_{a} 4 \mathrm{~b}$ is however rejected, because the results show a positive $(\beta=0.076)$ but insignificant $(t=1.370)$ correlation between the leadership practice enable others to act and business performance.

Hypothesis $\mathrm{H}_{a} 5 b$ posited a positive relationship between the leadership practice challenge the process and business performance. Table 4 indicates that there is a negative $(\beta=-0.121)$ but significant $(t=2.019)$ relationship between the leadership practice challenge the process and business performance. Therefore, $\mathrm{H}_{2} 5 \mathrm{~b}$ is also accepted.

These findings show that second generation leaders did not use all the leadership practices frequently and thus had marginal influence on business performance The inexperience of the successors based on the limited years in a leadership position resulted in them perhaps not understanding the leadership challenge. They were only able to challenge the process and encourage the heart. This could firstly be indicative of the younger generation of successors (akin to the Generation $Y$ cohort) that are more likely to challenge authority and consider themselves immune to rules. Secondly, they are also possibly able to be supportive and empathetic to their followers due to having a sense of belonging and camaraderie within the organisation if they were essentially raised in a family firm. However, leaders mobilise others to accomplish shared aspirations and this means that leadership is a relationship. It is possible that these successors have not yet developed the behaviours to use all these leadership practices sufficiently to develop these relationships. They were unable to model the way, inspire a shared vision and enable others to act, so these second generation leaders still need to develop these competencies.

Based on the findings, exemplary leadership behaviour makes a difference in an individual's commitment and performance at work. Leaders who more frequently engage in these leadership practices are considerably more effective. These results are supported by the research of Kouzes and Posner (2012:33) and in a similar study done by Weaver (2008) in the USA.

\section{Recommendations}

This research study proposes that the five leadership practices are important to the successful transfer of ownership and leadership of family firms to the second and later generations. However, first generation family business leaders should be aware that successors face different challenges than those faced by the first generation leaders. Second generation leaders may require attributes that are not necessarily the same as those needed by first generation leaders and appropriate transitioning mechanisms need to be put in place to address this. To this end, it is important that members of the second generation develop all the five leadership practices to ensure increased business performance and ultimately sustainability.

The demographic information indicated that 32 percent of the first generation leaders are over the age of 60 and are probably planning to retire in the next few years. This may result in a large number of new leaders being introduced into the economy. Creating and providing emerging family business leaders with leadership and training opportunities may help to improve the success rate of the second and later generation family businesses. Family businesses that develop these leadership practices may be poised to seek opportunities that allow them to capitalise on performance.

As the successors of family businesses were not engaging in all the leadership practices, they are the areas that require development to assist in improving business performance, namely model the way, inspire a shared vision and enable others to act. This implies that when it comes to setting an example, communicating vision and mobilising resources to allow for progress, the family business successors were lacking. First and second generation family business leaders should take note of these potential problem areas and use this research to improve on the leadership practices used in their respective businesses.

Figure 3 presents suggestions for developing the three leadership practices that were lacking within successors for the benefit of the family firms. 
Figure 3: Development of leadership practices
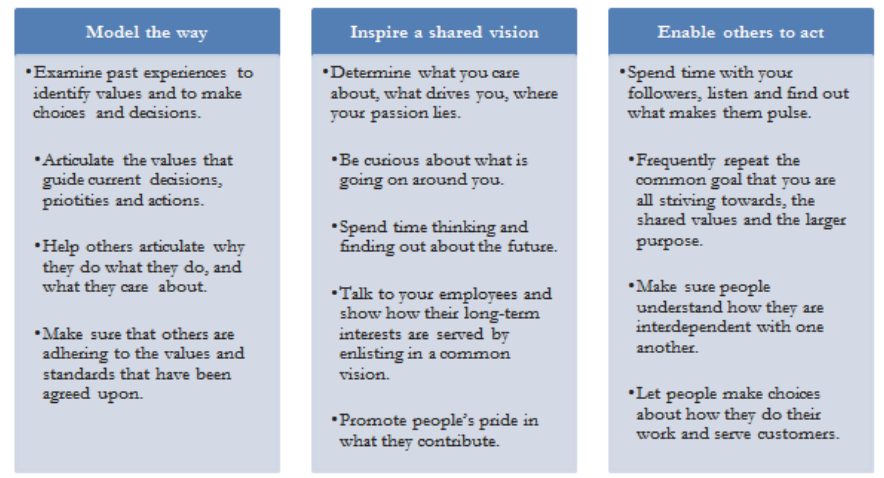

Since published evidence of a quantitative nature on the leadership practices and the correlation with business performance in small and medium-sized family businesses is still lacking, these findings present opportunities for further research.

\section{Limitations and Implications for Further Research}

Only family businesses located in the Sedibeng region in South Africa participated in this study, owing to the use of a non-probability, snowball convenience sample, therefore the sample cannot be considered representative of all small and medium-sized family businesses in South Africa. As a result, the findings reported cannot be generalised to the general family business population.

Another limitation of this study is that the current study required the family business leaders to fill in a self-reported version of the leadership practices inventory to record the leader's own perception of the leadership practices employed by him or her-self. It is possible that these own perceptions were biased in some form. Future studies could obtain additional observations by others evaluating the leadership practices of the leader and may provide a better assessment of the leaders' leadership practices rather than sole reliance on the self-reported version.

In addition, a mixed method approach might shed light on the lack of correlation between the individual leadership practices and the measures of business performance for the second generation business leaders. By using the qualitative component of interviews, researchers may determine what other factors could be occurring in the business environment. Some of these factors might be the role of other leaders within the business, the involvement of the founder on a regular basis or other economic factors such as a downturn in the economy.

\section{Concluding Remarks}

In an effort to try to explain the persistent failure rate of succeeding family businesses this study has contributed to the field of family business and leadership research by using the concept of quantifying leadership. This study also used the LPI to ascertain whether these leadership practices show a relationship with the business performance of the selected family businesses. The use of structural equation modelling to signify relationships enhances the contribution as most studies on family businesses have focused on case study methodology. Taking the theories related to leadership succession in family business into account, an empirical investigation into the five leadership practices has provided insight into where the potential problem areas lie in the second or later generation of family business leaders. This is an area of research that has not yet been conducted in South Africa and could result in the adaptation of entrepreneurial theory in the family business literature.

This stream of research may supply advances in not only theoretical knowledge, but also the management of the succession process in family businesses, an important consideration given the high failure rate in the transition of leadership. Family business leaders and advisors may use the information to provide platforms for the training of successors, or use the information when choosing a successor for the family business. This should allow for a measure of transference from first generation to second generation business leaders, and contribute to the sustained success of family firms. 


\section{References}

Ackerman, R. (2001). Hearing grasshopper's jump: the story of Raymond Ackerman as told to Denise Prichard. Cape Town: David Phillip.

Aronoff, C.E. (1998). Megatrends in family business. Family Business Review, 11(3),181-185.

Aronoff, C.E., Astrachan, J.H., \& Ward, J.L. (2002). Family business source book. $3^{\text {rd }}$ ed. Marietta, GA: Family Enterprise Publications.

Astrachan, J.H., \& Kolenko, T.A. (1994). A neglected factor explaining family business success: human resource practices. Family Business Review, 7(3), 251-262.

Astrachan, J.H., Klein, S.B., \& Smymios, K.X. (2002). The F-PEC scale of family influence: a proposal for solving the family business definition problem. Family Business Review, $\mathrm{XV}(1), 45-58$.

Astrachan, J.H., \& Shanker, M.C. (2003). Family businesses' contribution to the U.S. economy: a closer look. Family Business Review, 3(16), 211-219.

Avolio, B.J., \& Bass, B.M. (1998). Multifactor leadership questionnaire. Palo Alto, CA: Mind Garden.

Barack, J.A., \& Gantisky, J.B. (1995). Successful succession in family business. Family Business Review, 8(2), 131-155.

Bareither, H., \& Reischl, T. (2003). Planning a family and business legacy: a holistic approach to wealth transfer planning for entrepreneurs, business owners and family members. Family Business Review, 9(3), 203.

Bass, B.M., \& Bass, R. (2008). The Bass handbook of leadership. New York: The Free Press.

Basu, A. (2004). Entrepreneurial aspirations among family business owners: an analysis of ethnic business owners in the UK. International Journal of Entrepreneurial Behaviour \& Research, 10(1/2), 12-33.

Cater, J.J., \& Justis, R.T. (2009). The development of successors from followers to leaders in small family firms: an exploratory study. Family Business Review, 4, 109-110.

Chrisman, J.J., Chua, J.H., \& Steier, L.P. (2003). An introduction to theories of family business. Journal of Business Venturing, 18, 441448.

Chaharbaghi, K., \& Willis, R. (1999). Study and practice of sustainable development. Engineering Management Journal, 9(1), 41-48.

Collins, J. (2005). Level 5 leadership: the triumph of humility and fierce resolve. Harvard Business Review, 4, 136-146.

Corbetto, G., \& Salvato, C. (2004). Self-serving or self-actualizing? Models of man and agency costs in different types of family firms. Entrepreneurship Theory and Practice, 28(4), 355-362.

Day, D.V., \& Antonakis, J. (2012). The Nature of Leadership. $2^{\text {nd }}$ ed. SAGE: Los Angeles.

Duffy Atkin, P.A. (2002). Collective executive leadership: An exploration of this new leadership phenomenon and its relationship to organizational learning, performance and results [Abstract]. (Doctoral dissertation, Pepperdine University). Retrieved November 15, 2013, from ProQuest Digital Dissertations database.

Enger, J.M. (2004). Review of leadership practices inventory - individual contributor. Mental Measurements Yearbook, 14. Retrieved, October 16, 2013, from EBSCOhost database.

Fiedler, F.E. (1996). Research on leadership selection and training: one view of the future. Administrative Science Quarterly, 41(2), 241250.

Flören, R.H. (2002). Crown princes in the clay. In Farrington, S.M. 2009. Sibling Partnerships in South African small and medium-sized family businesses. Doctoral thesis, University of Port Elizabeth, Port Elizabeth.

Gersick, K.E., Davis, J.A., Mccollom Hampton, M.M., \& Lansberg, I. (1997). Generation to generation - life cycles of the family business. Boston: Harvard Business School Press.

Grote, J. (2003). Conflicting generations: a new theory of family business rivalry. Family Business Review, 16(20), 113-124.

Haber, S., \& Reichel, A. (2005). Identifying performance measures of small ventrues - The case of the tourism industry. Journal of Small Business Management, 43, 257-287.

Hair, J.F, Black, W.C., Babin, B.J., \& Anderson, R.E. (2010). Multivariate Data Analysis: A Global Perspective. $7^{\text {th }}$ ed. Upper Saddle River, New Jersey: Prentice Hall.

Handler, W.C. (1994). Succession in family business: a review of the research. Family Business Review, 7(2), 133-157.

Hugo, P.F. (1996). The alternative business entities available to family businesses with succession as the ultimate goal. MBA treatise, Graduate School of Business, University of Stellenbosch, Stellenbosch.

Ibrahim, A.B., \& Ellis, W.H. (2004). Family business management: concepts and practice. $2^{\text {nd }}$ ed. Dubuque, la.: Kendall/Hunt.

Ibrahim, A.B., Soufani, K., Poutziouris, P., \& Lam, J. (2004). Qualities of an effective successor: the role of education and training. Education \& Training, 46(8/9), 474-480.

Ibrahim, A.B., Soufani, K., \& Lam, J. (2001). A study of succession in a family. Firm Business Review. 17(3), 245-258.

IFERA. (2003). Family business dominate International Family Enterprise Research Academy (IFERA). Family Business Review, 16(4), 235-240.

Kets De Vries, M.F.R. (1996). Family businesses: human dilemmas in the family firm. London: ITB Press.

Kouzes, J. M., \& Posner, B.Z. (2012). The leadership challenge: how to make extraordinary things happen in organizations. $5^{\text {th }}$ ed. San Francisco: Jossey-Bass.

Lansberg, I. (1988). The succession conspiracy. In Aronoff, C.E., Astrachan, J.H. \& Ward, J.L., eds. Family business sourcebook II. Marietta, GA: Business Owner Resources.

Lansberg, I. (1999). Succeeding generations: Realising the dreams of families in business. Boston: Harvard Business School Press.

Lea, J.W. (1991). Keeping it in the family: successful succession of the family business. New York: Wiley. 
Lee, J. (2004). The effects of family ownership and management on firm performance. SAM Advanced Management Journal, 46-53.

Lee, J. (2006). Impact of family relationships on attitudes of the second generation in family business. Family Business Review, 21(3), 175-191.

Littunen, H., \& Hyrsky, K. (2000). The early entrepreneurial stage in Finnish family and nonfamily firms. Family Business review, 13(1), 41-54.

Longenecker, J.G., Moore, C.W., Petty, J.W., \& Palich, L.E. (2006). Small business management: an entrepreneurial emphasis. Mason: Thomson South-Western.

Maas, G., Van Der Merwe, S., \& Venter, E. (2005). Family businesses in South Africa: a practical governance guide. Stellenbosch: Content Solutions.

Matsuno, K., \& Mentzer, J.T. (2000). The effects of strategy type on the market orientation-performance relationship. Journal of Marketing, 64(4), 1-16.

Miller, N.J., \& Besser, T.L. (2005). Exploring decision strategies and evaluations of performance by networked and non-networked small U.S. businesses. Journal of Developmental Entrepreneurship, 10(2), 167-186. Retrieved April 6, 2013, from ProQuest database.

Morck, R., \& Yeung, B. (2004). Family control and the rent seeking society, Entrepreneurship: Theory and Practice, 28(4), $391-409$.

Morris, H.M., Williams, R.O., Allen, J.A., \& Avila, R.A. (1997). Correlates of success in family business transitions. Journal of Business Venturing, 12, 385-401.

Murray, B. (2003). The succession transition process: A longitudinal perspective. Family Business Review, 16(1), 17-33.

Neubauer, F., \& Lank, A.G. (1998). The Family business - its governance for sustainability. New York; Routledge.

Neuman, L.W. (2006). Social research methods: Qualitative and quantitative approaches. $6^{\text {th }}$ ed. Boston: Pearson International Education.

Nunnally, J.C. (1978). Psychometric theory. $2^{\text {nd }}$ ed. New York : McGraw-Hill.

Plakoyiannaki, E., Tzokas, N., Dimitratos, P., \& Saren, M. (2008). How critical is employee orientation for customer relationship management? Insights from a case study. Journal of Management Studies, 45(2), 268-293.

Poza, E.J. (2010). Family Business. $3^{\text {rd }}$ ed. Mason, OH: Thomson South-Western.

Poza, E.J. (2014). Family Business. $4^{\text {th }}$ ed. Ohio: Southern-Western Cengage Learning.

Rasheed, H.S. (2005). Turnaround strategies for declining small business: The effects of performance and resources. Journal of Developmental Entrepreneurship, 10, 239-252.

Rubenson, G. C., \& Gupta, A.K. (1996). The initial succession: a contingency model of founder tenure. Entrepreneurship Theory and Practice, 20(4), 21-35.

Rwigema, H., \& Venter, R. (2004). Advanced Entrepreneurship. Cape Town: Oxford University Press.

Sharma, P., Chrisman, J.J., \& Chau, J.H. (2003). Succession planning as planned behaviour: Some empirical results. Family Business Review, 16(1), 1-16.

Tio, J., \& Kleiner, B.H. (2005). How to be an effective chief executive officer of a family owned business. Management Research News, 28(11/12), 142-153.

Van Duijn, C.W.J., Breunesse, J.J., \& Malindz, M. (2007). BEE in family businesses. Unpublished report presented during the Entrepreneurship and Small Business Management Course, Port Elizabeth: NMMU.

Ward, J.L. (1987). Keeping the family business healthy: how to plan for continuing growth, profitability, and family leadership. San Francisco: Jossey-Bass.

Weaver, P.Q. (2008). Relationships between leadership practices of founders and successors and economic performance of select family firms. Unpublished doctoral thesis. University of Phoenix.

Wolff, J.A., \& Pett, T.L. (2006). Small-firm performance: Modeling the role of product and process improvements. Journal of Small Business Management, 44(2), 268-284. Retrieved April 20, 2013, from ProQuest database. 